\title{
DEVELOPMENT ASSESSMENT OF THE SINGAPORE LAND: A GIS SPATIAL- TEMPORAL APPROACH BASED ON LAND COVER ANALYSIS
}

\author{
Mărgărit-Mircea NISTOR ${ }^{1 *}$, Harianto RAHARDJO ${ }^{1}$, Alfrendo SATYANAGA ${ }^{1}$
}

DOI: 10.21163/GT_2019.142.06

\begin{abstract}
:
Urban indicators plays an important role in the planning and sustainable development of the cities. This paper presents a methodology to determine the favorability index for development of Singapore based on land cover. The 'City Index' of Singapore was calculated using five indicators - Social, Environmental, Industrialization, Economic, and Naturality. Two indices 'Environmental Capacity of Development' and 'Land Restriction' were used as correction factors in the Singapore favorability index for development determination. The analysis of indicators and final index were carried out based on the land cover of Singapore in 2014 and in 2030 projection. A high favorability index was observed in the central and northwestern sides, in Pulau Tekong and Pulau Ubin 'Environmental Capacity of Development' factor is related to the significant importance in the natural territories and in the reclamation areas. Hence the central, North-West and surrounding islands registered higher values (close to 1) of the "Environmental Capacity of Development". The high values of the 'Land Restriction' factor indicating many infrastructures and special use areas spread over the Singapore Island. On the other hand, the moderate values of the 'Land Restriction' factor are observed in few locations from North, South, central and northeastern islands of Singapore. The 'Favorability index for development of Singapore' depicts the central and northwestern sides together with the Tekong and Pulau Ubin as high favourable areas. The southern part of Singapore, near the coastline and the eastern extremity are predicted to be favourable areas in the future due to new reclamation lands extensions. The approach presented in this paper is indispensable tool for the Singapore urban decisions and future planning. Moreover, the methodology is useful and it can be adapted for large cities or metropolitan areas of capitals.
\end{abstract}

Key-words: City development, Development indicators, Land covers analysis, Naturality, Singapore.

\section{INTRODUCTION}

Regional development is highly dependent on the Globalization trajectories. In general, the administrative units of the countries are commonly structured in each activity, such that the main sectors of industry, agriculture, and tertiary are very well defined. Christaller (1933, 1966) indicated in his'Central Place Theory'that the spatiality of the concentric development is observed at regional scale which is mainly occurred in the cities. This concept illustrates the development of cities and metropolitan areas around of core with

\footnotetext{
${ }^{1}$ Nanyang Technological University, School of Civil and Environmental Engineering, 50 Nanyang Avenue, Singapore. *Corresponding author email: margarit@ntu.edu.sg Co-authorse-mail: chrahardjo@ntu.edu.sg,alfrendo@ntu.edu.sg
} 
main functionality and concentric zones with various functions in the industry, agriculture, and others sectors. Further, his theory was analysed by Beguin (1996) and it was used in the regional geography and urban planning. Based on the natural landscapes, including the relief and geomorphology, rivers, coastal areas, and succession of cities, the anisotropic regions were defined. On the high specialization influence and technologies improvement, the cities of the world have a development that tends to population growth and area extension. The population migration is focussing on viable and functional cities, gross domestic product, and main economic attractions to build-up the careers and society. Many sectors in the big urban areas become fully occupied and they adopt multi-functionality for their prosperity. Thus, the strategic plans and immediate future actions should be analysed for correct decisions on a favourable territory.

The changes at the global scale are firstly induced related to the climate warming (Stocks et al., 1998; Shaver et al., 2000; Haeberli et al., 1999; IPCC, 2001; Stavig et al., 2005; The Canadian Centre for Climate Modelling, 2014) illustrating major changes after the ice mass changes (Kargel et al., 2005; Oerlemans, 2005; Shahgedanova et al., 2005; Dong et al., 2013; Xie et al., 2013; Elfarrak et al., 2014; Nistor \& Petcu, 2015), reduction of river flows, depletion in the spring discharge, and poor groundwater quality due to the increases of the groundwater temperature (Taylor and Stefan, 2009; Figura et al., 2011; Kløve et al., 2012; Haldorsen et al., 2012; Kløve et al., 2014). Due to these negative issues, the ecosystems and anthropic areas require a good management for the next future planning. Moreover, the agricultural and industrial activities are continuing to be significant indicators for the cities and regions sustainability.

Up to present, the functionality of the cities and its sustainable development were very well documented (Ayram, 2017). Singh et al. (2012) indicated that the man indicators should be considered in the sustainability assessment. They used four core indicators for sustainable development based on the United Nations Commission for Sustainable Development framework presented by Labuschagnea et al. (2005). These indicators refer to social, economic, environmental, and institutional. Ayram et al. (2017) used the land use intensity, time of human landscape intervention, and biophysical vulnerability to revise a multidimensional spatial human footprint index in Mexico and to analyze the effects of landscape trans-formation on the habitat mammal species. Sands \& Podmore (2000) developed an Environmental favorability index for development using 15 sub-indices to analyse the corn and wheat agricultural production systems in southeastern Colorado. Holden (2006) carried out the urban indicators for the sustainability development in the Vancouver area, Canada.

Gardi et al. (2010) found an optimal index for the Emilia-Romagna region from Italy based on the CORINE Land Cover database. They propose four determinant indicators (urbanization, industrialization, agricultural, and agricultural intensity) and two state indicators (naturality and biodiversity). The formula and the indicators calculation for the Land Use favorability index for development were established by Gardi et al. (2010).

In the large city-state as Singapore, some activity sectors are very well defined, but others are inferred between them (i.e. educational institutions and residential areas). To determine the favourable index in Singapore, five main indicators and two correction factors have been set and implemented in a new framework in this study. These indicators were calculated based on the land cover of Singapore in two periods of time (i) current period (2014 master plan) and (ii) near-future period (2030 master plan). The study area includes the main land of Singapore and the surrounding islands. 


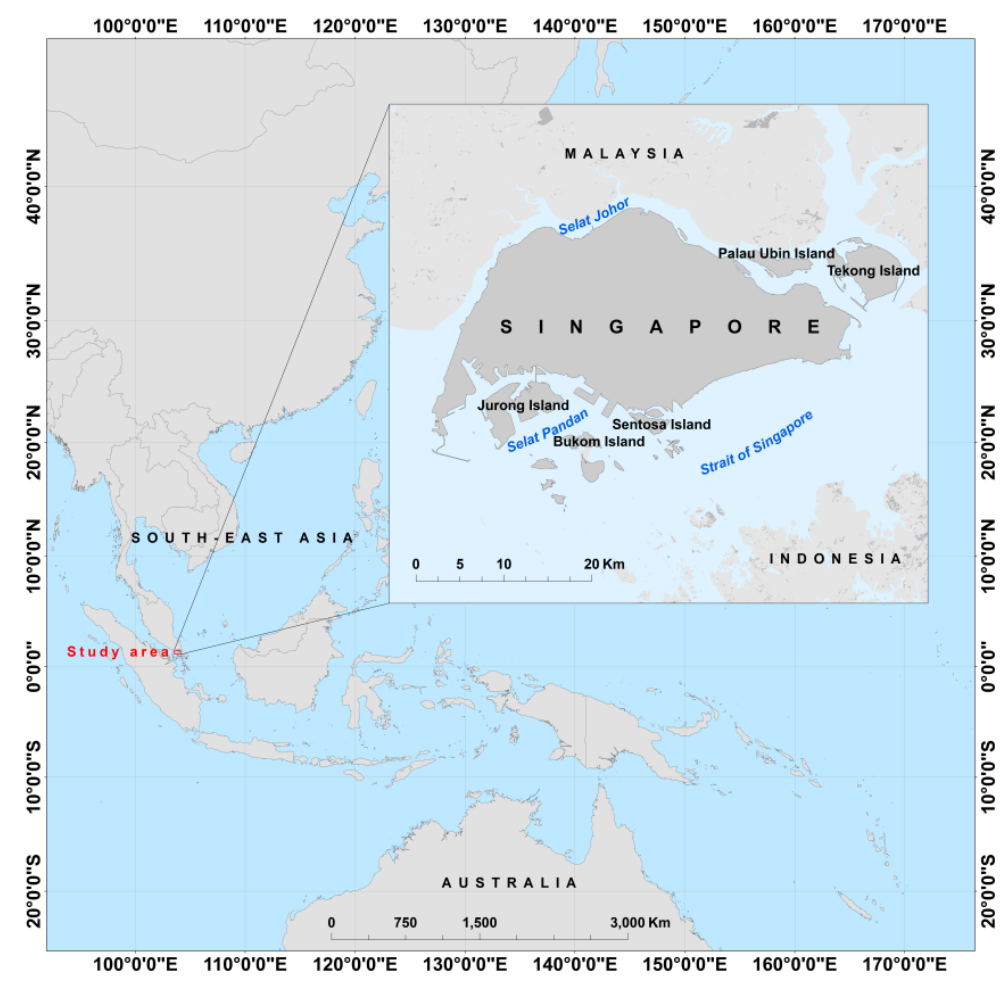

Fig. 1. Location of Singapore city-state on South-East Asia map.

\section{MATERIALS AND METHODS}

\subsection{Study area}

Singapore is a city-state located in the South-East Asia, between Indonesia and Malaysia (Fig. 1). The main island is around $50 \mathrm{~km}$ in length and $25 \mathrm{~km}$ in width. Numerous islands could be found around the Singapore, including in principal the Jurong, Sentosa, and Bukom islads in the South and Pulau Ubin and Pulau Tekong in the NorthEast. Land cover in Singapore register a dynamic growth of the artificial areas (Tab. 1).

The development of the Singapore started since 1950s years and currently, more than $60 \%$ of the territory is artificial area, mainly with residential and industrial areas (Fig. 2). North-West and central areas as well as the Pulau Ubin, Pulau Tekong, and Sentosa islands shows a large area of open and recreational space, while in southern sides and Jurong Island, there are predominantly the industrial area. The infrastructure areas are mainly composed by harbour sectors designated to navy boats and heavy platforms for shipping and the Changi Airport. Sparsely are presented the areas with special use, reserve sites, and lakes. Table 2 reports the area values $\left(\mathrm{km}^{2}\right.$ and \%) of each land cover type in Singapore related to 2014 and 2030.

The complex demographic aspects and the actual construction plans signal the necessity of a detailed analysis of the land use sustainability. 

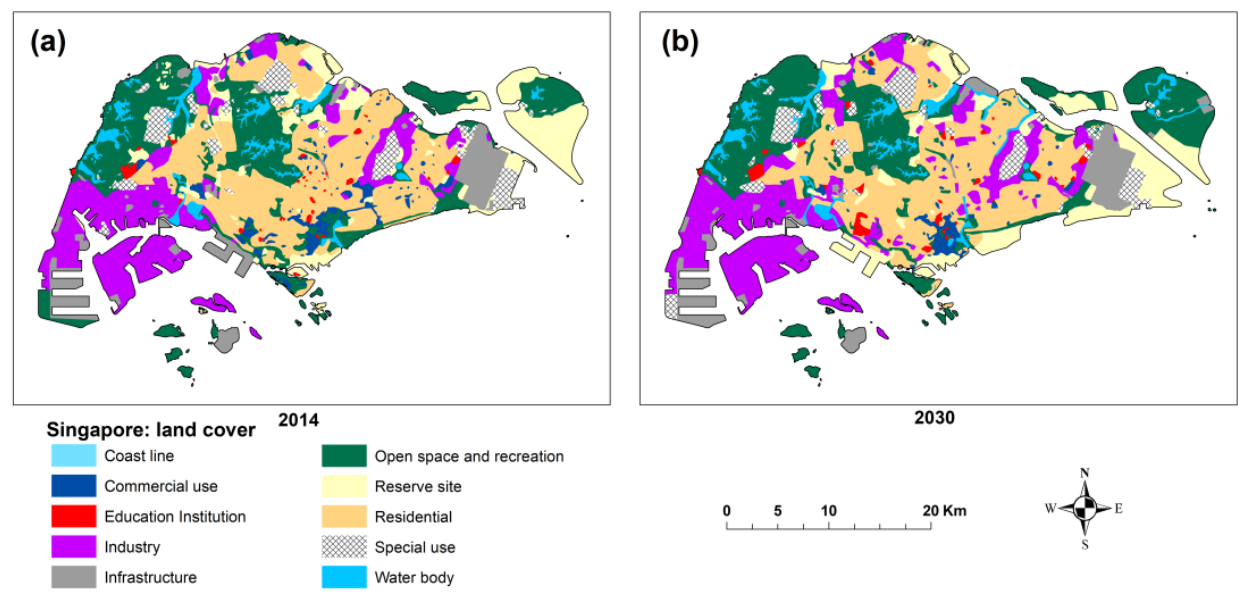

Fig. 2. a) Land cover map of Singapore related to 2014;

b) Land cover map of Singapore related to 2030 .

Source: Urban Redevelopment Authority: Master Plan for 2014 and 2030.

(https://www.ura.gov.sg/uol/).

Land use in Singapore: current (2014) and near-term (2030) periods

Table 1.

\begin{tabular}{lrrrr}
\hline \multirow{1}{*}{ Land type } & \multicolumn{2}{c}{2014} & \multicolumn{2}{c}{2030} \\
& Area $\left(\mathrm{km}^{2}\right)$ & Area $(\%)$ & Area $\left(\mathrm{km}^{2}\right)$ & Area $(\%)$ \\
\hline Coast line & 13.84 & 1.73 & 13.41 & 1.61 \\
Commercial use & 21.64 & 2.71 & 12.28 & 1.48 \\
Education Institution & 6.97 & 0.87 & 11.21 & 1.35 \\
Industry & 134.02 & 16.79 & 152.82 & 18.41 \\
Infrastructure & 57.37 & 7.19 & 58.75 & 7.08 \\
Open space and recreation & 180.08 & 22.56 & 189.68 & 22.85 \\
Reserve site & 93.14 & 11.67 & 92.74 & 11.17 \\
Residential & 216.01 & 27.06 & 214.81 & 25.87 \\
Special use & 44.80 & 5.61 & 46.33 & 5.58 \\
Water body & 30.30 & 3.80 & 38.24 & 4.61 \\
\hline Total & 798.18 & 100.00 & 830.28 & 100.00 \\
\hline
\end{tabular}

\subsection{Overview of the methodology and data}

The favorability index for development is a product of the 'City Index'calculated using five indicators and the 'Environmental Capacity of Development', further divided to 'Land Restriction'. The appropriate indicators for 'City Index' determination are selected based on common factors used for the cities development and Singapore Island. These indicators are: 'Social', 'Environmental', 'Industrialization', 'Economic', and 'Naturality'. Each one 
reflects the capacity of the development in various sectors and it is easy to be extracted from the land cover or master plan of the city. Thus, the Social Indicator was defined in this study based on residential, educational institution, infrastructure, and special use areas. The 'Environmental Indicator' is composed from reserve sites, open space and recreational areas, water bodies, and coastline areas. Industrialization, Economic, and Naturality (i.e. coastline, water bodies, and open space) indicators are defined as industrial areas, commercial units, and open space respectively. The Economic Indicator could also include other variables (i.e. gross domestic product) which have direct impact for the economy.

In the favorability index for development determination, we applied two correction factors specifically for Singapore. The 'Environmental Capacity of Development' represents a strong development factor and it is composed by reserve sites, coastline, and open space areas. These areas are most available territory for the new built-up and reclamation lands (i.e. coastal zone). The 'Land Restriction for Development' is a weak factor for development and it is composed mainly of areas with very low capacity for development and society wellness. The areas considered for the correction factor were normalized from 0.5 (low impact) to 1 (high impact) following the Gardi et al. (2010) approach. The nil values in this type of normalization were avoided due to the mathematical operations, but also because some land cover designation could be changed into another. Figure 3 shows the general framework of the favorability index determination methodology into the urban areas.

Table 2.

Normalized values of land cover for determination of favorability index for development of Singapore

\begin{tabular}{lcc}
\hline Land type & $\begin{array}{c}\text { Environmental Capacity for } \\
\text { Development }\end{array}$ & $\begin{array}{c}\text { Land Restriction for } \\
\text { Development }\end{array}$ \\
\hline Coast line & 0.90 & 0.50 \\
Commercial use & 0.50 & 0.75 \\
Education & & \\
Institution & 0.50 & 0.75 \\
Industry & 0.50 & 0.75 \\
Infrastructure & 0.50 & 1.00 \\
Open space and & & \\
recreation & 0.80 & 0.75 \\
Reserve site & 1.00 & 0.50 \\
Residential & 0.50 & 0.75 \\
Special use & 0.50 & 1.00 \\
Water body & 0.50 & 1.00 \\
\hline
\end{tabular}

The main data used in the paper refers to the master plan of Singapore, published in 2014 and the masterplan projection for year of 2030. The raster maps of master plan, for both periods were collected from the Urban Redevelopment Authority site (https://www.ura.gov.sg/uol/master-plan) and were georeferenced in ArcGIS 10.5 environment. The vector data of the land cover pattern was extracted from the raster grid data and they were divided into 10 classes, as it was proposed in the Master Plan of Singapore. Then, the vector data of land cover for 2014 and 2030 were used to calculate the indicators values, i.e. the 'City Index', the correction factors of 'Environmental Capacity of Development' and 'Land Restriction for Development', and the 'favorability index for development of Singapore'. 


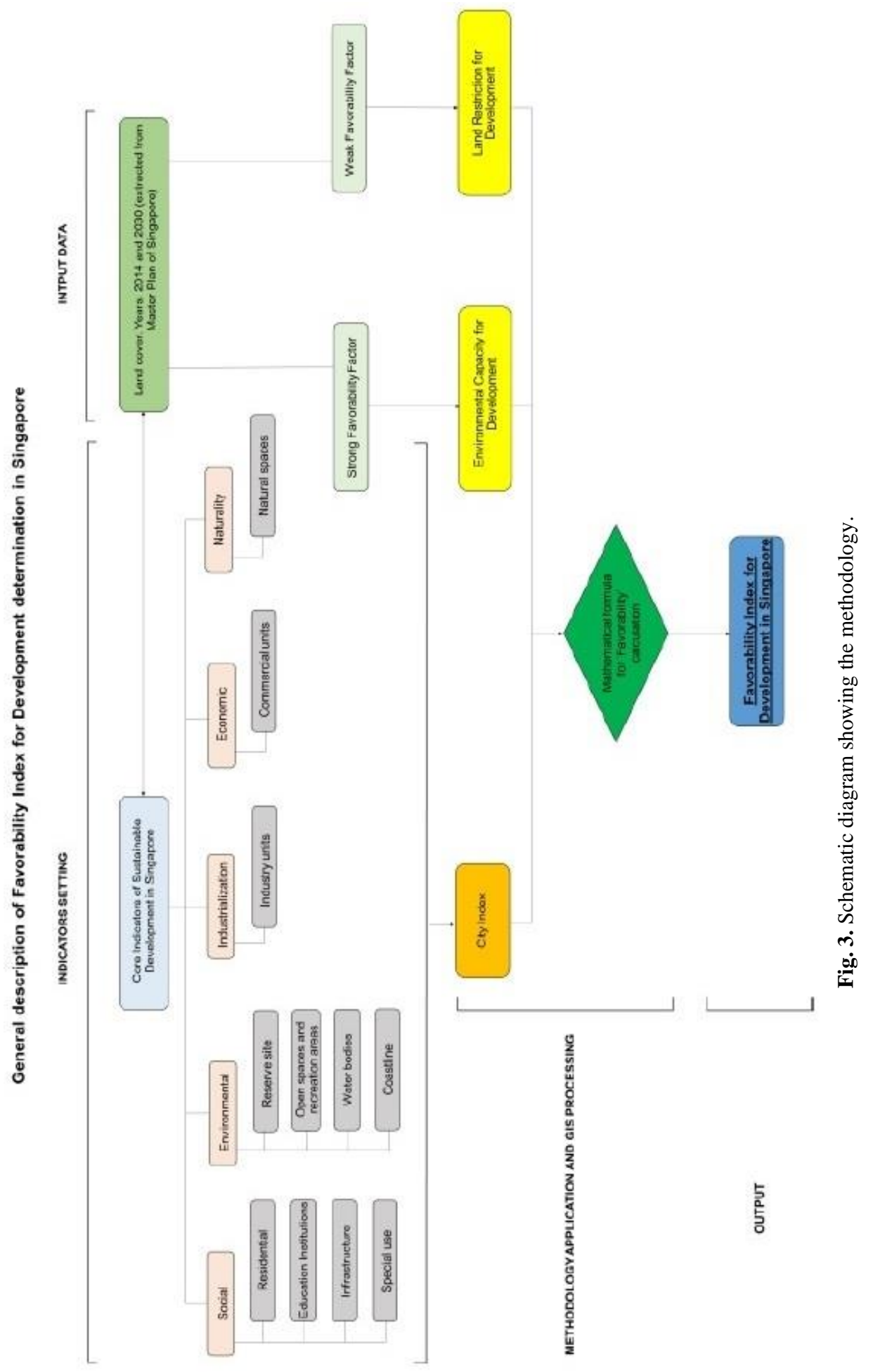




\subsection{Indicators setting and calculation}

The five indicators: 'Social', 'Environmental', 'Industrialization', 'Economic', and 'Naturality', were incorporated in Eq. (1) to calculate the 'City Index' of Singapore. The network $1 \mathrm{X} 1 \mathrm{~km}$ was used to create the equal units (cells) over the Singapore territory. The indicators were incorporated in each cell adopting the Gardi et al. (2010) method. They divided the areas of the indicators in every unit to the area of the unit. To incorporate the variation of land use in each province and the complexity of these provinces, the biodiversity index was used in their study. Using the mathematical formula, Gardi et al. (2010) determined the Land Use favorability index for development at regional scale in Emilia-Romagna from Italy. In this study, the formula used by Gardi et al. (2010) was adopted by replacing biodiversity with two correction factors which are more representative for the city development. These two factors are 'Environmental Capacity of Development' and 'Land Restriction for Development' and they were used in the determination of favorability index for development of Singapore (Eq. (2)). The correction factors used in this paper contains normalized values in range from 0.5 (minimum value) to 1 (maximum value) as proposed by Gardi et al. (2010). The minimum and maximum values are determined for types of land cover which represent strong and weak capacity for development in Singapore. Other land cover types were classified accordingly between 0.5 and 1 (Tab. 2). Note that the minimum values of 0.5 is not representing the nil influence, but the most unlikely for the index. The moderate influence was set between 0.5 and 1 .

City Index $=($ SocInd $\times 20)+($ IndusInd $\times 10+$ EcInd $\times 2)+($ EnviInd $\times 20)+($ NatInd $\times 20)$

where:

SocInd $=$ Social Indicator

IndusInd = Industrialization Indicator

EcInd = Economic Indicator

EnviInd = Environmental Indicator

NatInd = Naturality Indicator

Favorability index for development of Singapore $=\frac{\text { City Index } \times \text { Environmental Capacity of Development }}{\text { Land Restriction for Development }}$

\section{RESULTS}

\subsection{Core indicators and 'City Index' in Singapore}

The indicators, 'City Index', correction factors, and favorability index for development of Singapore' were calculated based on the proposed methodology in this study, for years of 2014 and 2030. Figure 4 illustrates the variations of different indicators over Singapore island. In 2014, the Social indicator indicates high values (above 0.8) in the southern, central, northern and eastern parts of Singapore (Fig. 4a), while in 2030, the Social indicator increases slightly in the South and West parts (Fig. 4b). In 2014, the results of the Environmental indicator shows maximum values (1) in the West, West-central, and East of Singapore, in Pulau Ubin and Pulau Tekong. In addition, high values could also be identified in the South and South-West near the coastline of Singapore. Figures $\mathbf{4 c}$ and $\mathbf{4 d}$ depict the Environmental indicator for both periods. Industrialization indicator is more developed in the western and southwestern sides of Singapore including Jurong Island (Fig. 4e and 4f). 

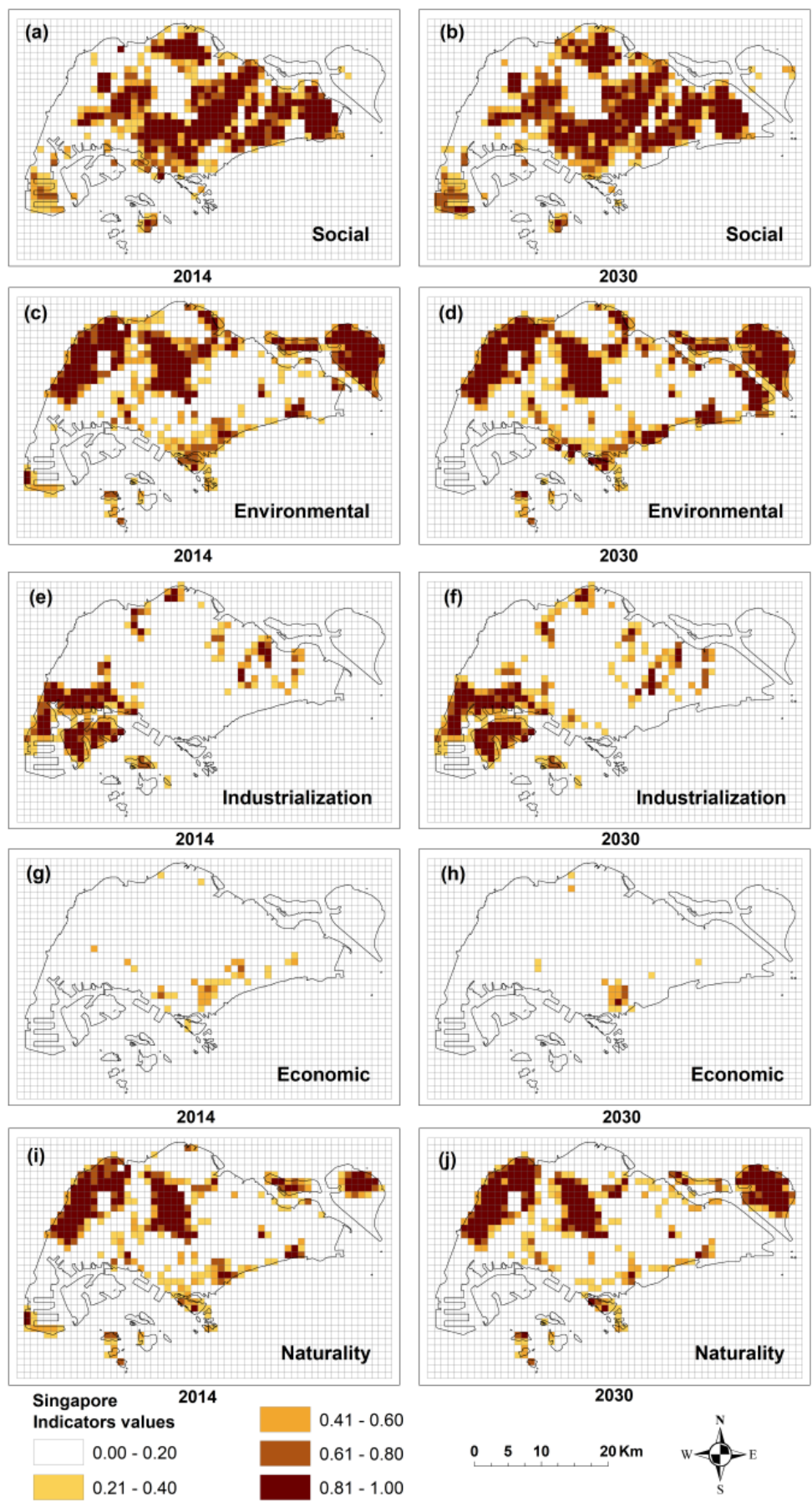

Fig. 4. Spatiality of indicators used into City Index calculation for Singapore. 
Few territories with industry activities are present in the East, East-central and North. Between years 2014 and 2030, the increase in the industrialization indicator is observed in the central, northern, western and Jurong Island parts. The Economic indicator is identified in the South of Singapore, while it is very sparsely over South-West, South-East, and North of Singapore. Figures $\mathbf{4 g}$ and $\mathbf{4 h}$ bring forward the spatial distribution of the Economic indicator in Singapore. Interestingly for the future period, this indicator will increase up to 1 and will be more concentrated in the South of Singapore. An extended territory is defined by 'Naturality' indicator, mainly in the northwestern, central, and southern parts of Singapore. Sentosa, Pulau Ubin and Pulau Tekong register high values (over 0.8) of this indicator in 2014 (Fig. 4i) while Tekong Island is expected to be more natural land in 2030 (Fig. 4j).

Five indicators are required to calculate the 'City Index'in Singapore. For both periods, the 'City Index' shows a large territory with medium values especially in the residential areas and infrastructure places (Fig. 5a and 5b). The high values were depicted mainly in the natural areas and open spaces, Pulau Ubin and Tekong islands. The low values overlap with the industrial areas and spread more in the West, East, and North of Singapore. In the future period, the highest values of 'City Index' are expected to decrease in the central and southern sides, while in the northwestern and Tekong Island 'City Index' is expected to occupy larger territory.

\subsection{Correction factors}

Many successful built-up projects can be found in the open space and in the reclamation areas. Figures 6a and $\mathbf{6 b}$ show the 'Environmental Capacity of Development' correction factor in 2014 and 2030. The lands with low restriction values extend to the North, South, and East on the coastline as well as to the north-eastern islands. Future projection in 2030 indicates major changes in the map with favourable lands are expected to be found on the South and East coastline. The low values of 'Environmental Capacity of Development'can be observed especially in the residential and industrial areas and cover the West, East, Eastcentral and North territory of Singapore for both periods. The maximum values of 'Land Restriction for Development'are sparsely distributed in territory, but mainly occupy few land of North, East and West sides. These territories overlap with the infrastructure, body water, and special use lands. Major part of the Singapore Island has values between 0.5 and 0.75 and only few lands with low restriction are present in the North, South, sparsely in central, and in the Palau Ubin and Tekong islands. Figures 7a and $7 \mathbf{b}$ depict the spatial distribution of 'Land Restriction for Development' factor over Singapore.

\subsection{Favorability index for development of Singapore}

Utilizing 'City Index'and two correction factors, the 'favorability index for development of Singapore' were calculated for years 2014 and 2030. In 2014, the low and very low favorability was depicted in the southwestern side of Singapore including Jurong Island, in the eastern side, and some parts of South and North of Singapore. These areas corresponded to the field with the industrial lands, residential areas, and infrastructure. The medium favorability index for development of Singapore'is observed sparsely within Singapore island in 2014 (i.e. some territories cab found in the South, central, North-West, and in the North of Pulau Ubin) which overlaps with commercial and open space areas. 

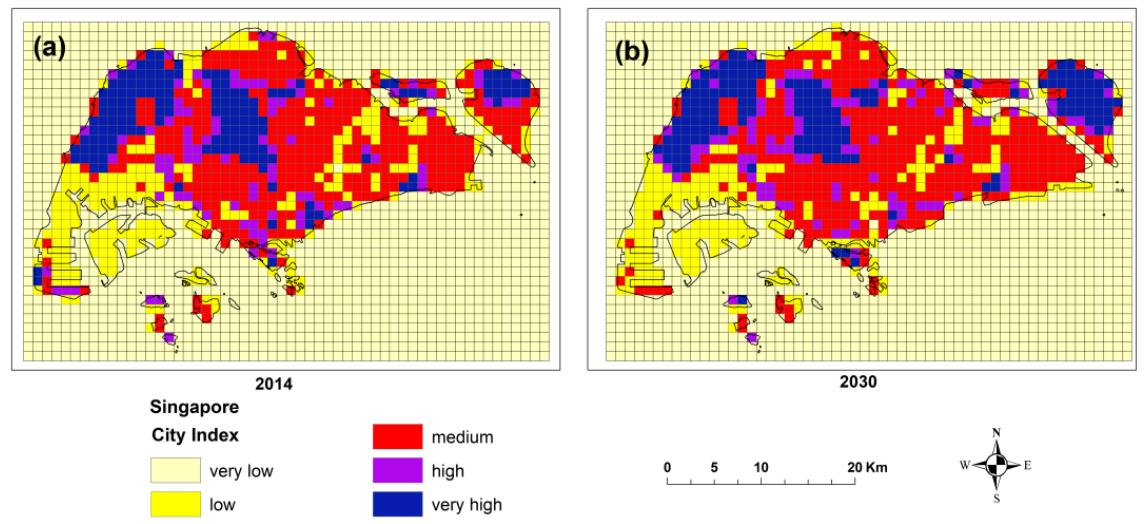

Fig. 5. City Index distribution over Singapore. a. City Index in 2014. b. City Index in 2030.
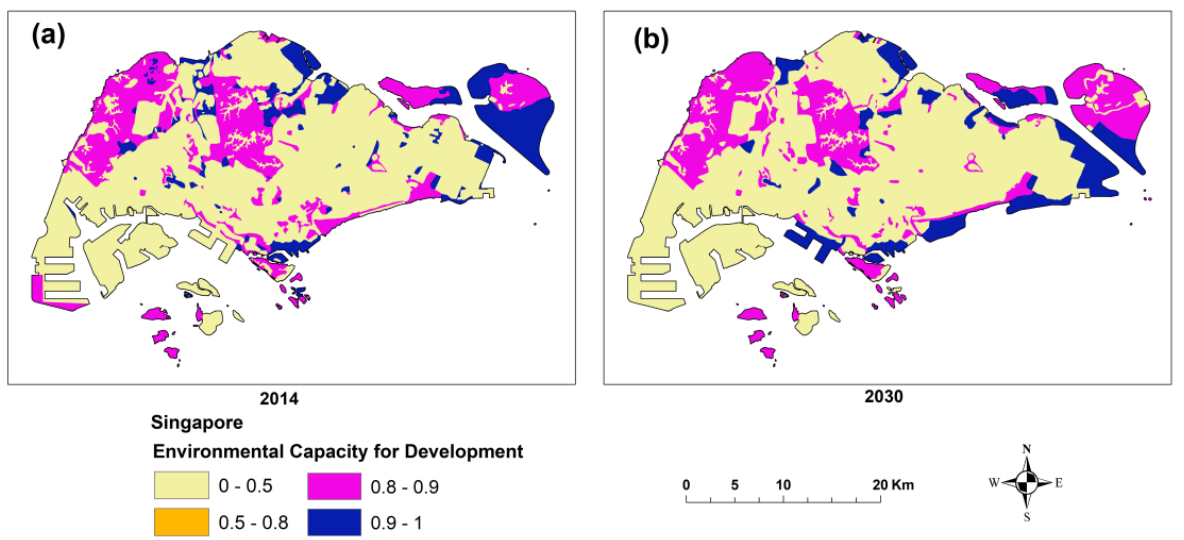

Fig. 6. Environmental Capacity of Development factor over Singapore. a. in 2014. b. in 2030.
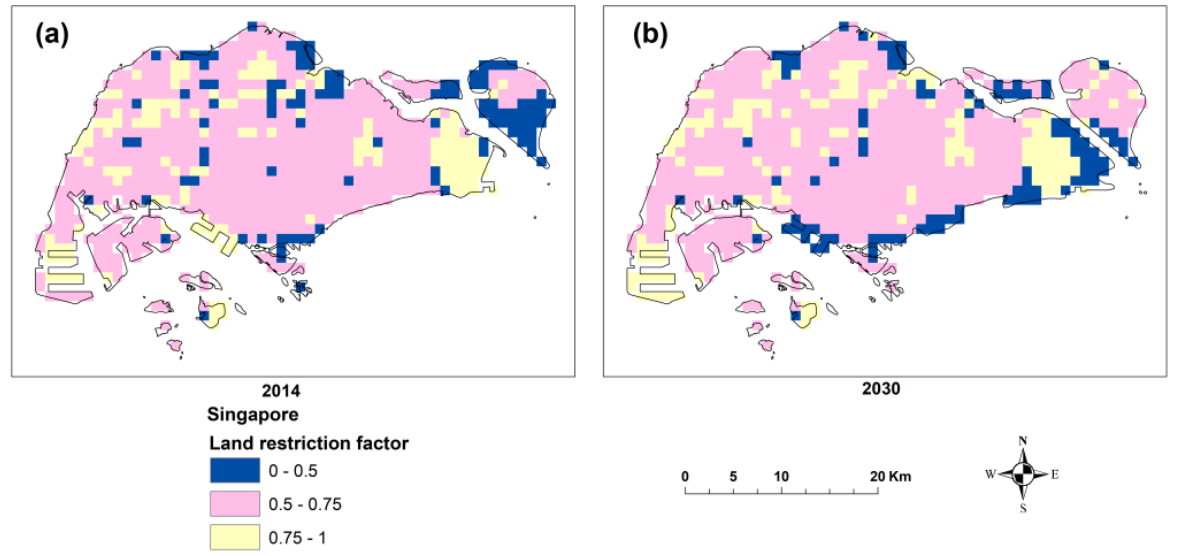

Fig. 7. Land Restriction for Development factor over Singapore. a. in 2014. b. in 2030. 
The high and very high 'favorability index for development of Singapore' were indicated in the West and central sides of the main island with few territories in South, East, and South-West of Singapore. Pulau Ubin and Pulau Tekong are classified under high and very high favourable areas, while the southern islands has land that is classified under very low, low, medium and high favourable areas. Figures 8a and $\mathbf{8 b}$ show the favorability index for development of Singapore for the years 2014 and 2030.

In 2030, the favorability index for development Index of Singapore is very low and low in the South-West, East, and few sides in South and North of Singapore. This pattern follows the spatial distribution of favorability index for development of Singapore in 2014. The numbers of areas in medium class decrease whereas the numbers of areas in high and very high classes increase. The medium favourable areas can be observed in the South, West, West-central, and North sides, while the high and very high favourable areas are indicated in the central, West and North-West, and in the South of Singapore. Interestingly, the favourable indexes of Pulau Ubin, Pulau Tekong and the eastern extremity of the Singapore main island are expected to increase due to the reclamation land in 2030. In both periods, the high and very high favourable have direct relationship with the reserve sites, open space and recreation areas.

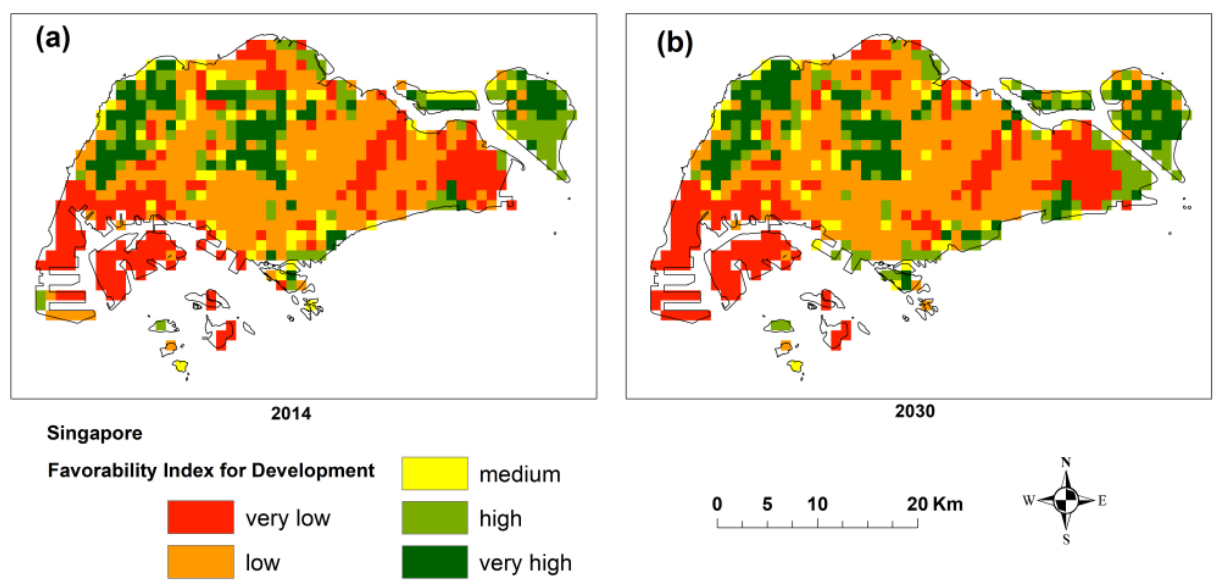

Fig. 8. Favorability index map for development in Singapore. a. in 2014. b. in 2030.

\section{DISCUSSION}

The main goal of this paper was to propose a methodology to assess the favourable index in the urban areas using the terrain data of land cover and land use. A new method was proposed for the city-state of Singapore considering 'City Index' and two correction factors such as 'Environmental Capacity of Development' and 'Land Restriction for Development'. The methodology was applied for two GIS database for years of 2014 and 2030 to assess the development of Singapore in 2014 and 2030. The spatial distribution of five indicators was served to calculate the 'City Index' over Singapore. The high and very high values of the index overlap to areas which can support the new constructions and development, showing that the open space and reserve sites are the land with high favorability for development in the urban area. In opposite, the industrial zones of the 
Singapore have low 'City Index', because these lands cannot support the development of the city from society point of view (i.e. educational and institutions units). In the same time, the airport and harbours areas have low favourable index.

As expected, Pulau Ubin and Pulau Tekong represent the lands with high 'City Index' due to the green spaces and environmental spaces. As Singapore has limited spaces, the nonconstructed areas and reserve sites play very important roles in the development of of Singapore. Nistor \& Petcu (2014) observed that the ecosystems plays an important role, not only in the natural areas, but also inside the cities. Thus, the harmony of the built-up and parks areas could be inferred to manage the development of the city. The coastline represent in Singapore a strong opportunity and a big challenge for the extension of the city. New reclamation lands are proposed for Singapore to 2030 fact for that the coastal areas constitute a high favorability of development.

The new method has been applied on Singapore territory to assess the favorability for development of the city in two different periods. The proposed procedure combined several comprehensive indicators extracted from land cover in two different times. The analysis included the 'City Index'and two correction factors which refer to the Singapore territory. The selection of indicators and correction factors could be slightly modified from place to place. Based on these analyses, the land with high favorability were identified on the North, West, Pulau Ubin and Pulau Tekong. The approach is a new spatio-temporal method that contributes to specific literature of cities development. Our results represent a useful tool for the urban planning and future strategy at spatial level of Singapore. This study is limited by the weights setting and the combination of layer although this doesn't affect too much in the final analysis.

\section{CONCLUSIONS}

Based on the land cover data for 2014 and 2030, the 'favorability index for development of Singapore'was calculated. Five indicators mostly used for the cities development assessment have been analysed in the present study at spatial scale of Singapore to carry out the 'City Index'. This index combined with two correction factors contributed to the final calculation of the favorability index for development of Singapore. In 2014, it was observed that the central, North-West, Pulau Ubin and Pulau Tekong Island sides of Singapore shows a high and very high favorability. In 2030, the eastern side and the southeastern coastline parts show an important switch in the favorability for development increase due to the new reclamation lands.

Even if the procedure is complex and requires several calculations, the method presented here reflects an appropriate way in which the cities development should be calculated. Moreover, with slightly modifications, the method that we proposed here could be easily adapted to other study cases.

The results of the present paper bring forward the relationship of the land cover of the Singapore city-state and various indicators used in the favorability for development. Normally, in the large cities the open areas and non-constructed land may constitute an advantage for the urban area development while the infrastructure and industrial areas are more rigid and supply only the internal connections, workforce. In case of Singapore, the reserve sites and coastal areas represent two strong development factors due to the terrain availability for development capacity, new reclamation land and maybe for new residences. The Pulau Ubin and Pulau Tekong, which are closer to the main island and also the largest 
of Singapore territory, may be connected to the main land and could represent a significant pole for future development: new traditional neighbourhoods, research centres.

This study contributes to the scientific methodology, which evaluate the favourable indicators at spatial scale and proposes a procedure to integrate the strong and weak factor and calculate the favorability index for development of Singapore. Moreover, the maps and provided details represent a tool for urban planning and management strategy for Singapore. Future investigations could be drawn on particular sites of Singapore and an interactive favorability model could be proposed in ArcGIS as a new tool.

\section{Acknowledgements}

The authors would like to thank URA Agency for the land use data of Singapore.

\section{REFERENCES}

Ayrama, C.A.C., Mendoza, M.E., Etter, A. \& Salicrup, D.R.P. (2017) Anthropogenic impact on habitat connectivity: A multidimensionalhuman footprint index evaluated in a highly biodiverse landscape of Mexico. Ecological Indicators, 72, 895-909.

Beguin, H. (1992) Christaller's central place postulates. A Comentary. Ann. Reg. Sci., 26, 209-229.

Christaller, W. (1933) Die zentralen Orte in Süddeutschland. Fischer, Jena.

Christaller, W. (1966) Central places in Southern Germany. Prentice-Hall, Englewood Cliffs.

Dong, P., Wang, C. \& Ding, J. (2013) Estimating glacier volume loss used remotely sensed images, digital elevation data, and GIS modelling. International Journal of Remote Sensing, 34(24), $8881-8892$.

Elfarrak, H., Hakdaoui, M. \& Fikri, A. (2014) Development of Vulnerability through the DRASTIC Method and Geographic Information System (GIS) (Case Groundwater of Berrchid), Morocco. Journal of Geographic Information System, 6, 45-58.

Figura, S., Livingstone, D.M., Hoehn, E. \& Kipfer, R. (2011) Regime shift in groundwater temperature triggered by the Arctic Oscillation. Geophysical Research Letters, 38(L23401), 1-5.

Gardi, C., Bosco, C., Rusco, E. \& Montanerella, L. (2010) An analysis of the Land Use Sustainability Index (LUSI) at territorial scale based on Corine Land Cover. Management of Environmental Quality: An International Journal, 21(5), 680-694.

Haldorsen, S., Heim, M. \& van der Ploeg, M. (2012) Impacts of Climate Change on Groundwater in Permafrost Areas - Case Study from Svalbard, Norway. pp. 323-340. In: Treidel, H., MartinBordes, J.J., Gurdak, J.J. (Eds.), Climate Change Effects on Groundwater Resources: A Global Synthesis of Findings and Recommendations. International Association of Hydrogeologists (IAH). International Contributions to Hydrogeology. Taylor \& Francis Publishing, pp. 414.

Haeberli, W.R., Frauenfelder, R., Hoelzle, M. \& Maisch, M. (1999) On rates and acceleration trends of global glacier mass changes. Geografiska Annaler, Series A, Physical Geography, 81A, 585595.

Holden, M. (2006) Urban indicators and the integrative ideals of cities. Cities, 23(3), 170-183.

IPCC. (2001) Climate change 2001: the scientific basis. In: Houghton, J.T., Ding, Y., Griggs, D.J., Noguer, M., van der Linden, P.J., Dai, X. (Eds), Contribution of Working Group I to the Third Assessment Report of the Intergovernmental Panel on Climate Change. Cambridge University Press: Cambridge and New York, New York, pp. 881.

Kargel, J.S., Abrams, M.J., Bishop, M.P., Bush, A., Hamilton, G., Jiskoot, H., Kääb, A., Kieffer, H.H., Lee, E.M., Paul, F., Rau, F., Raup, B., Shroder, J.F., Soltesz, D., Stainforth, S., Stearns, L. $\&$ Wessels, R. (2005) Multispectral imaging contributions to global land ice measurements from space. Remote Sensing of Environment, 99(1), 187-219.

Kløve, B., Ala-Aho, P., Okkonen, J. \& Rossi, P. (2012) Possible Effects of Climate Change on Hydrogeological Systems: Results From Research on Esker Aquifers in Northern Finland, pp. 305-322. In: Treidel, H., Martin-Bordes, J.J., Gurdak, J.J. (Eds.), Climate Change Effects on Groundwater Resources: A Global Synthesis of Findings and Recommendations. International 
Association of Hydrogeologists (IAH). International Contributions to Hydrogeology. Taylor \& Francis Publishing, pp. 414.

Kløve, B., Ala-Aho, P., Bertrand, G., Gurdak, J.J., Kupfersberger, H., Kværner, J., Muotka, T., Mykrä, H., Preda, E., Rossi, P., Bertacchi Uvo, C., Velasco, C. \& Pulido-Velazquez, M. (2014) Climate change impacts on groundwater and dependent ecosystems. Journal of Hydrology, 518, 250-266.

Labuschagnea, C., Brenta, A.C., Ron, P.G. \& Van Ercka, P.G. (2005) Assessing the sustainability performances of industries. Journal of Cleaner Production, 13, 373-385.

Nistor, M.M. \& Petcu, I.M. (2014) The role of glaciers in the evolution of Prince William Sound landscape ecosystems, Alaska. STUDIA UBB AMBIENTUM, LIX(1-2), 97-109.

Nistor, M.M. \& Petcu, M.I. (2015) Quantitative analysis of glaciers changes from Passage Canal based on GIS and satellite images, South Alaska. Applied Ecology and Environmental Research, 13(2), 535-549.

Oerlemans, J. (2005) Extracting a Climate Signal from 169 Glacier Records. Science, 308, 675-677.

Sands, G.R. \& Podmorea, T.H. (2000) A generalized environmental sustainability index for agricultural systems. Agriculture, Ecosystems and Environment, 79, 29-41.

Shahgedanova, M., Stokes, C.R., Gurney, S.D. \& Popovnin, V. (2005) Interactions between mass balance, atmospheric circulation, and recent climate change on the Djankuat Glacier, Caucasus Mountains, Russia. Journal of Geophysical Research, 110(D16107), 1-12.

Shaver, G.R., Canadell, J., Chapin III, F.S., Gurevitch, J., Harte, J., Henry, G. et al. (2000) Global warming and terrestrial ecosystems: a conceptual framework for analysis. BioScience, 50(10), $871-882$.

Singh, R.K., Murty, H.R., Gupta, S.K. \& Dikshit, A.K. (2012) An overview of sustainability assessment methodologies. Ecological Indicators, 15, 81-299.

Stavig, L., Collins, L., Hager, C., Herring, M., Brown, E. \& Locklar, E. (2005) The effects of climate change on Cordova, Alaska on the Prince William Sound. Alaska Tsunami Papers, The National Ocean Sciences Bowl. https://seagrant.uaf.edu/nosb/papers/2005/cordova-nurds.html (accessed 23 April 2014).

Stocks, B.J., Fosberg, M.A., Lynham, T.J., Mearns, L., Wotton, B.M., Yang, Q., et al. (1998) Climate change and forest fire potential in Russian and Canadian boreal forests. Clim. Change, 38, 1-13.

Taylor, C.A. \& Stefan, H.G. (2009) Shallow groundwater temperature response to climate change and urbanization. Journal of Hydrology, 375(3-4), 601-612.

The Canadian Centre for Climate Modelling and Analysis. (2014) The first generation coupled global climate model publishing web. URL: http://www.ec.gc.ca/ccmaccccma/default.asp?lang=En\&n=540909E4-1 (accessed 20 March 2015).

Urban Redevelopment Authority. (2017) Plans and Maps. URL: https://www.ura.gov.sg/uol/masterplan. (accessed on June 10, 2017)

Xie, X., Li, Y.X., Li, R., Zhang, Y., Huo, Y., Bao, Y., \& Shen, S. (2013) Hyperspectral characteristics and growth monitoring of rice (Oryza sativa) under asymmetric warming. International Journal of Remote Sensing, 34(23), 8449-8462. 